\title{
The Issues of Secession in the Process of the Rise and Fall of States in the Light of International Law
}

\section{Introduction}

The rise and fall of a state are events that produce specific legal consequences. These effects, especially in the field of succession, are regulated - to a greater or lesser extent - by international law ${ }^{1}$. An equally important issue is to determine whether the very rise and fall of the state is regulated by international law. International law deals with the state from outside, as an existing phenomenon. This statement remains valid as far as the creation of the state is concerned. As for the fall of the state, international law has never really been a mere witness of this event. If in earlier times, annexation was one of the reasons for the state's collapse (if not the main reason), it was international law that determined the conditions of its legality. To a much greater extent, the fall of the state is regulated by modern international law. This is connected not only with the prohibition on the use of force and the resulting prohibition on annexation, but also with the right of nations to self-determination. Annexation is nowadays an illegal act and therefore does not cause the state to fall, not only because it is a consequence of the use of force, but also because it is incompatible with the right of peoples and nations to self-determination. A nation can not be deprived of its own state against its will.

The right of nations to self-determination is in this respect complementary to the basic law of the state - the right to exist. According to contemporary international law, the loss of statehood (and thus the loss of subjectivity of international law) can only take place on a voluntary basis. However, there are also reasons for the fall of a state, for which international law was and still is really only a witness (e.g. when the existing state is divided into several parts: In any case, it can be initially established that at least some cases of state collapse are regulated by international law. The situation is different

1 Vid. R. Kwiecień, Status prawny i rola państw w spoteczności międzynarodowej a podmiotowe granice prawa międzynarodowego, in: Państwo i terytorium w prawie międzynarodowym, eds. J. Menkes, E. Cała-Wacinkiewicz, Warszaw 2015, p. 85. 
when it comes to the creation of states. Here, international law is always only a witness registering the fact of its creation. For international law is indifferent with regard to the way in which the state was created. The rise of the state in the wake of a civil war is no less "legal" than the rise of states as a result of the independence granted by the metropolis. Those two examples of how the state was founded can and should be distinguished, but only from the point of view of the genesis of a given state, which may consist of various elements which are real (e.g. civil war) as well as legal (metropolitan legal acts, international agreements or the resolutions of relevant UN bodies) - in the light of international law there is no significance in the creation of a state. The creation of a state is an act independent of its origin. The state does not have to prove its genesis. Undoubtedly, these or other elements of the genesis of the state may facilitate or hinder the international situation of the state in the initial period of its existence, may, in particular, be important for its the recognition by other states ${ }^{2}$. In the course of the decolonization process that followed the Second World War, many new countries emerged, especially in Asia and Africa. These countries were created during the period when the right to self-determination became a rule of international law. Therefore, it can be said that these states arose as a result of the peoples of these countries (i.e. former colonial areas) realizing their right to self-determination. Due to the importance of the right to self-determination for the genesis of the state in our modern times, it requires more detailed discussion. On the other hand, the right to self-determination also plays a specific role in the event of a state failure.

\section{The Rise and Fall of the State and International Law}

According to C. Berezowski, there are certain reasons for the creation of a state, some of which are connected with the creation of a state in a direct way, and therefore they can be called causes that are closer to the creation of the state ${ }^{3}$. The entirety of these causes determines the formation of the state, constituting its genesis ${ }^{4}$. The beginning of the origin of the state is the first proximate cause, and thus certain events $t$ can be legally assessed as

2 Vid. E. Dynia, Uzananie państwa w prawie międzynarodowym, Rzeszów, 2017, p. 304.

3 Vid. C. Berezowski, Powstanie państwa polskiego w świetle prawa międzynarodowego, Warszawa 1934, p. 31; J. Crawford, The creation of states in international law, Oxford, Oxford University Press 2006; M. Shaw, International Law, Cambridge University Press, Cambridge 2003; T. Grant, The Recognition of States: Law and Practice in Debate and Evolution, Greenwood Publishing Group, Westport 1999; J. Crawford, The Creation of States in International Law, Oxford University Press, 2nd ed. Oxford 2006; A. Klafkowski, Prawo międzynarodowe publiczne, Warszawa 1971, p. 112.

4 C. Schreuer, The waning of the sovereign State: Towards a new paradigm for international law?, in: "European Journal of International Law", 1993, p. 447; Yearbook of the International Law Commission ,1975/II, p. 93. 
being in direct relation with the state's establishment ${ }^{5}$. According to C. Berezowski, the beginning of the genesis of the state takes place when the legal order existing in a given area makes concessions for emancipation, i.e. when it recognizes the possibility of its manifestations. In the event of an armed uprising, such a concession is the state's recognition of insurgents. An example of gaining independence following armed struggle is the creation of Algeria on July 1 1962. In 1954, the National Liberation Front was created, and in 1958 - the Provisional Government; on March 191962, in Evian, the French government concluded with the Provisional Government of Republic Algerian a socalled a general arrangement in which steps were planned which would lead to Algeria's independence. The overwhelming majority of states created as a result of decolonization gained independence through it being granted by the metropole. In these cases, the genesis of individual states consists of the legal acts of the metropolis. A special procedure was applicable to fiduciary areas. Here the decisive role was played by the resolutions of the UN General Assembly on the expiry of relevant trust agreements. C. Berezowski expresses the view that in the case of fiduciary areas, the beginning of a new state is the conclusion of a trust deed.

The legal acts of the metropole, agreements between the metropole and the organs of the national liberation movement, and the resolutions of the UN General Assembly concerning specific areas, are individualized acts as elements of the genesis of a specific state. In addition, the right to self-determination has a significant impact on the origin of the states that arise from the decolonization process. The right to self-determination understood as the right of colonial peoples to independence (part II) has the character of a general norm requiring colonial powers to carry out decolonization. If a colonial people make a claim for independence, grounds for this are found in international law and the metropole is obliged to take appropriate steps to satisfy this claim. In other words, the right to self-determination as a general norm will determine, as soon as the colonial people invoke it, the origin of the state. The creation of the state, however, is an act independent of its origin. Regardless of whether the home state cooperates in the process of the formation of a new state (i.e. according to the popular term "grants independence") or actively combats this process, the act of forming a state is of a primary nature. In the event of independence by the colonies, the metropole most often gradually passed individual competencies to local authorities. However, the original character of the act of establishing a state denies that the new state takes power away from another country. The power of the new state is always its primary power, which it derives from its own (and not given) sovereignty. The state always arises from its own power, regardless of its origin. The state is not, therefore, established on the basis of a legal act of the metropolis granting independence on the basis of an international treaty or a resolution of the

5 L. Antonowicz, Powstanie i upadek państw jako podmiotów prawa Międzynarodowego, in: “Sprawy Międzynarodowe”, 1968, no. 2, p. 71. 
General Assembly of the United Nations, as these are only elements of its genesis. Since the state is always created by its own power, the manner in which the state is founded cannot be subject to legal assessment. In the literature, the establishment of a state is usually referred to as a historical fact, poetic, sociological or extralegal. While circumstances connected with the creation of a state may be available for legal assessment, the examination of the compatibility of the act of establishing a state with international law is ruled out. From the point of view of international law, it is a matter of indifference how the state was created. International law does not accept earlier matters in relation to obtaining the characteristics of statehood and, consequently, remains indifferent to the ways that a certain community can use to form the state 6 . The legal status of a well-organized community is not affected by either the moral defects of the genesis or the violation of the law which could have been accompanied by its establishment. International law is limited to confirming the establishment of a state, referring to the features of statehood. While - as claimed by J. Symonides - the process and causes leading to the emergence of the state are of secondary significance, it is of prime importance to determine the criteria and the origin of the state, because with this date certain legal effects are connected, as the state it becomes the subject of rights and obligations ${ }^{7}$.

The existence of a state as a sovereign territorial organization determinines its effectiveness ${ }^{8}$. According to H. Kelsen, the moment of the establishment of the state is determined by positive international law in accordance with the principle of efficiency 9 . J. Symonides defines the principle of effectiveness as the principle according to which the actual (effective) existence or non-existence of the actual situations prescribed by international law causes ipso facto legal effects, or is a necessary condition for their emergence. Referring to the earlier considerations, it can be concluded that unless there is a legal norm regulating the way the state was established, the principle of effectiveness determines its creation. The principle of effectiveness does not regulate the way the state is founded, but - and this is its significance - allows the answers to two important questions to be ascertained: whether the state was founded at all and when it arose. As far as the first issue is concerned, in accordance with the principle of effectiveness, a specific factual situation must be not only real: "The condition of the effectiveness of the actual

6 T. Grant, op. cit.; C. Drew, The Meaning of Self-determination: The Stealing of the Sahara Redux?, Karin Arts \& Pedro Pinto Leite, International law and the question of Western Sahara (Leiden, IPJET, 2007), p. 87.

7 J. Symonides, Terytorium państwowe w świetle zasady efektywności, Torun 1971, pp. 178-179; W. Multan, J. Symonides: Powstanie Ludowej Republiki Bengalii - niektóre aspekty prawnomiędzynarodowe, in: "Sprawy Międzynarodowe" 1972, nr 6, pp. 50-51.

8 J. Sondel, 'Ius postliminii', jako podstawa uznania ciagtości I i II oraz II i III Rzeczypospolitej, [w:] Na szlakach Niepodlegtej. Polska myśl polityczna i prawna w latach 1918-1939, ed. M. Marszał, M. Sadowski, Wrocław 2009, p. 22.

9 H. Kelsen, Principles of International Law, New York 1959, s. 258. 
situation is to have a firm and stable character. The uncertain and unstable situation usually does not have legal consequences."This condition of stability and sustainability plays an important role in the formation of the state. The requirement of stability and durability, stemming from the rule of principle, makes it possible to state which territorial communities that regard themselves as states. Therefore, Mandżukuo (1932-1945), Slovakia (1939-1945) and Croatia (1941-1945) were not states operating under international law. Rhodesia, whose authorities proclaimed independence from British law in 1965, was not a state, but not because of its genesis and its system, which did not correspond to the will of the majority of the population, but because the existing situation there did not meet the requirement durability and stability ${ }^{10}$.

\section{The Right to Self-Determination and the Rise and Fall of the State}

The principle of self-determination means not only the right to create one's own state ${ }^{11}$. Its reach also includes nations that already have their own countries. In this case, the subject of the right to self-determination is a nation identified with the entire population of an already existing state. The right to self-determination here means the right of every nation to choose the form of government and the political and social system that suits $\mathrm{it}^{12}$. The principle of self-determination is here closely related to the principle of sovereignty and the principle of non-interference in the internal affairs of other states. Since every nation has the right to determine, without foreign interference, the system of its state, it is even more entitled to maintain this state. No nation, therefore, can be deprived of its own state against its will ${ }^{13}$. In this context, the principle of self-determination is closely related to the prohibition of the use of force and the threat of its use. It also complements the

10 G. Kreijen. ÔThe Transformation of Sovereignty and African Independence: No Shortcuts to StatehoodÕ, in: State Sovereignty and International Governance, ed. G. Kreijen, Oxford University Press, Oxford 2002, p. 45.

11 C. Drew. The Meaning of Self-determination: The Stealing of the Sabara Redux?, in: Karin Arts \& Pedro Pinto Leite, International law and the question of Western Sahara (Leiden, IPJET, 2007), p. 87. "Wszystkie narody mają prawo do samostanowienia. Z mocy tego prawa swobodnie określają one swój status polityczny i swobodnie zapewniają swój rozwój gospodarczy, społeczny i kulturalny”. Art. 1 ust. 1 Międzynarodowego Paktu Praw Obywatelskich i Politycznych (Dz.U. z 1977 r. Nr 38, poz. 167, zał.).

12 F. Przetacznik, The Basic Collective Human Right to Self-Determination of Peoples and Nation as a Prerequisite for Peace: its Philosophical Background and Practical Application, in: "Revue de Droit International. De Sciences diplomatiques et politiques. The International Law Review” 1/1992, p. 25.

13 Vid.J. Kolasa, Odzyskanie przez Polskę niepodlegtości w1918 $r$. wświetle prawa międzynarodowego, in: "Przegląd Sejmowy" 5/2008, p. 29; Vid. S. Hubert, Odbudowa państwa polskiego jako problemat prawa narodów, Lwów 1934; idem, Rozbiory i odrodzenie Rzeczypospolitej. Zagadnienie prawa międzynarodowego, Lwów 1937; J. Sondel, op. cit., p. 22. 
fundamental right of the state to exist. The right to self-determination also implies that every nation can renounce its own statehood, either by establishing with a new nation or nations a new state (the unification of states) or by joining another state (incorporation).

If, however, there are circumstances that raise doubts as to the voluntary nature of such an act, it can be assumed that the right to self-determination implies the presumption of the continued existence of the state even after its collapse. It seems that such a presumption is a fundamental consequence of the right to self-determination considered in connection with the problems of the state's collapse. This presumption now serves to reinforce the general presumption of the continuity of the state that derives from international law. The right of every nation to form its own state was formulated as a political postulate. According to W.I. Lenin “... through self-determination of nations is understood as their state detachment from the national teams, it means the creation of a self-contained nation-state." Lenin's concept of the right to self-determination, as opposed to the Western (Wilsonian) concept of the right to self-determination, did not include colonial lands, excluding the provinces of the Ottoman Empire, if they were considered as "colonial areas"14. In any case - as L. Dembiński states - "irrespective of various theoretical interpretations of the Wilsonian and Leninist concept of the principle of self-determination, their political application was almost entirely restricted to the European peoples who had never had, or were deprived of, independent existence" ${ }^{15}$. In the interwar period, the principle of self-determination was the only political principle, but it played a significant role as the only basis for shaping the international order. The right to self-determination was elevated to the rank of a principle of international law only with the entry into force of the United Nations Charter. However, the provisions of the UN Charter are very general in this respect (Articles 1 and 55). The development of the principle of self-determination took place in the resolutions of the UN General Assembly. Resolution 637 A / VII concerning the right of peoples and people for self-determination and the declaration on granting independence to colonial countries and peoples (res 1514 / XV) should be mentioned here ${ }^{16}$. In a broader context, the principle of self-determination has been defined in the declaration of the international rules regarding friendly relations and the cooperation of states in accordance

14 W. I. Lenin: Oprawie narodów do samostanowienia, in: Dzieła wybrane, Warszawa 1949, t.1, p.70. 15 L. Dembiński: Samostanowienie w prawie i praktyce ONZ, Warszawa 1969, p. 20.

16 At the opposite extreme, however, the right of peoples to self-determination was invoked as the basis for the intervention of the organized international community. The UN Charter begins with the words, "We, the peoples..." and the right of self-determination, based on the UN Charter, has emerged as a fundamental principle of modern international law. In an opinion on Namibia, given in 1970 in relation to the illegal presence of South Africa in the territory concerned, the International Court of Justice had already declared that "the injured entity is a people which must look to the international community for assistance" Legal Consequences for States of the Continued Presence of South Africa in Namibia [South West Africa ] Notwithstanding Security Council Resolution 276, Advisory Opinion, I.C.J. Reports 1971, p. 56. 
with the UN Charter (Resolution 2625 / XXV). In a special context, the right to selfdetermination is dealt with by the UN General Assembly resolution on the definition of aggression (Res. 3314 / XXIX). Naturally, Art. 1 of both UN Covenants on Human Rights establishes the right to self-determination for "all peoples". In UN practice, there is a special relationship between the right of peoples to self-determination and decolonization. In Resolution 637 / A / VII, the General Assembly recommended that "States member of the United Nations recognize and support the implementation of the right to self-rule nations that are under their administration and facilitate the exercise of this right for nations in such areas, in accordance with the principles and spirit of the United Nations Charter, in each area and in accordance with the free will of the nations concerned." Resolution 1514 / XV /, calling for independence for countries and peoples, clearly highlights this relationship. Similar conclusions can be drawn from the content of other UN resolutions. The connection between the right of peoples to self-determination and decolonization was also emphasized in doctrine. L. Dembiński states that from the Second World War "the problem of self-management was closely related to the problem of the colony, and so much that it was impossible to separate them separately." A similar opinion is expressed by $\mathrm{H}$. Bokor-Szegó when he writes that nowadays a typical form of applying the right to self-determination is the separation of a territory dependent on the colonial power and the creation of its own non-independent state. International community has recognized that people of dependent areas has the right to independence, what it confirmed by the practice on the United Nations, its States and the views of scholars.

\section{Secession as a Form of Insurrection and Collapse of the State}

Does the right to self-determination also mean the right of orthers than colonial peoples to independence? Does the right to self-determination include the so-called right to secession $^{17}$ ? This issue is contentious. In addition to the view that "the introduction of selfdetermination into international law necessarily entails the recognition of the right to secession", one can find the opinions of authors who deny the existence of such a right or at least doubt its existence ${ }^{18}$. Considering this problem, it must be claimed that existence or non-existence can only be inferred from the practice of the post-World War II period. Since before that the right to self-determination was only a political and moral prin-

17 G. Abi-Saab, Conclusion, in: Secession : A Contemporary International Law Perspective, dir. M. Kohen, Cambridge University Press, 2006, p. 470; W. Czapliński, Samostanowienie-secesja-uznanie (uwagi na tle inkorporacja Krymu do Federacji Rosyjskiej, [w:] Państwo i teryritorium w prawie międzynarodowym, eds. J. Menkes, E. Cała-Wacinkiewicz, Warszawa 2015, pp. 245-246.

18 S. Kaur, Self-Determination in International Law, in: "Indian Journal of International Law" 1970, vol. 10, p. 493; R. Emerson, Self-Determination, in: "American Journal of International Law" 1971, vol. 65, p. 464; M. Shaw, International Law, Cambridge University Press, Cambridge 2003. 
ciple, from the fact that with the independence of some European nations after the First World War the right to self-determination was invoked, no conclusions can be drawn about the "right to secession". By secession, we mean the separation of an integral part of the state territory. Most countries ceased to treat independence in the colonial areas at the time when self-determination became the rule of international law as secession. According to the prevailing view, the area is not self-governing is not an integral part of the metropolitan territory. The United Nations Declaration in Resolution 2625 / XXV states that the territory of a colony or other non-dependent area has, by virtue of the UN Charter, a status which is distinct and different from the territory administering it, while such separate and different status under the Charter should exist until such time as the people of the colony or non-dependent area will exercise their right to self-determination in accordance with the Charter, in particular with its aims and principles ${ }^{19}$. For this reason - as L. Antonowicz notes - the issue of the independence of colonial territories differs from the issue of secession of other types of territories ${ }^{20}$. In the course of the codification work on the secession of states in relation to the treaties, the International Law Commission clearly opposed the independence of the colonies in the UN period, the former cases of independence by the colonies, and so in the period when they were considered "as being in the full sense, the territories of the colonial power."

The right of the colonial peoples to independence is, therefore, an issue different from the "right to secession", i.e. on the basis of the right of these peoples to independence, one can not infer the right to secession to exist. Based on the current practice of states and international organizations (e.g. the negative position of the United Nations and the Organization of African Unity with regard to the movements of secession in Katanga and Biafra) the thesis can be put forward that international law does not acknowledge the right to secession, because - in the light of this practice - it does not stem from the principle of self-determination of the state. The principle of international law: the "right to secession", as the right of a specific nation or people inhabiting an integral part of the state (and a territorially constituent minority in it) to separate from it and create its own state, would be - in the light of understood practice - only a political principle. This is, of course, the transformation of the future "right to secession" into a legal principle. The above thesis is not the only possible interpretation of the principle of self-determination. In any case, it must be emphasized at this point that the statement that international law does not acknowledge the "right to secession" cannot lead to the conclusion that it is forbidden. In particular, the principle of territorial integrity does not prohibit secession, as this applies to relations between states, not relations between a state and a population of territories within its territory. But secession violates the principles of territorial

19 Vid. J. Symonides, op. cit., p. 178-179; W. Multan, J. Symonides, op. cit., pp. 50-51.

20 L. Antonowicz: Likwidacja kolonializmu ze stanowiska prawa międzynarodowego, Warszawa 1964, pp. 131-132. 
integrity. Due to the fact that UN practice limited the application of the right to self-determination to colonial peoples, the establishment of a state in the former colonial area puts them in a situation which in the light of UN law is more advantageous than that of the situation of astate resulting from secession. However, the right to self-determination itself does not create any state, neither does the state create a legal act of another state or states. The state always arises from its own power (chapter III). Therefore, the right to self-determination matters only to the genesis of the state.

\section{Conclusion}

In the end, it must be emphasized that if international law "does not prohibit" secession, this does not mean that it refers back to the state and secessionist group. The right of sel - determination remains hostile to secession. Establishing a presumption against the effectiveness of secession and in favor of the territorial integrity of the pre-existing State. Effectivities thus often have a greater role to play in terms of acquiescence, or rather the resignation of the pre-existing State (which, compelled by the force of facts, realizes that it no longer really has a choice and abandons its attempts at recovery), than that of the "automatic" birth of a new state.

The myth of the "absolute neutrality" of the law, advocated by the theory of effectiveness, does not, therefore, seem to correspond exactly to reality. Relying on, inter alia, the resolutions and declarations of the Security Council concerning secessionist crises in Bosnia, Croatia, Georgia, Moldova, Azerbaijan etc., some writers have even wondered if some emerging trends indicate a prohibition on secession and the legalization of repression. Perhaps the argument would be stronger if the case of Kosovo did not weaken it not so much, which is a real "anomaly" within the system and could constitute a very dangerous precedent, as evidenced by the numerous references to the possible independence of Kosovo by various independence movements or other actors.

\section{Literature}

Klafkowski A., Prawo międzynarodowe publiczne, Warszawa 1971.

Boutros Boutros Ghali, Building Peace and Development 1994 - Annual Report on the Work of the Organization, New York, 1994, p. 147.

Berezowski C., Powstanie państwa polskiego w świetle prawa międzynarodowego, Warszawa 1934. Drew C., The Meaning of Self-determination: The Stealing of the Sahara Redux?, Karin Arts $\&$ Pedro Pinto Leite, International law and the question of Western Sahara (Leiden, IPJET, 2007). 
140 | Adam Mickiewicz University Law Review

Schreuer C., The waning of the sovereign State: Towards a new paradigm for international law?, "European Journal of International Law" 1993.

Dynia E., Uzananie państwa w prawie międzynarodowym, Rzeszów 2017.

Abi-Saab G., Conclusion, Secession: A Contemporary International Law Perspective, dir. M. Kohen, Cambridge University Press, 2006.

Kreijen G., The Transformation of Sovereignty and African Independence: No Shortcuts to Statehood, State Sovereignty and International Governance, ed. G. Kreijen, Oxford University Press, Oxford 2002.

Kelsen H., Principles of International Law, New York 1959.

Brownlie I., System of the Law of Nations: State Responsibility, part 1, Oxford 1983.

Crawford J., The Creation of States in International Law, Oxford University Press, 2nd ed., Oxford 2006.

Kolasa J., Odzyskanie przez Polskęniepodlegtości w1918r. wświetle prawa międzynarodowego, „Przegląd Sejmowy” 5/2008.

Sondel J., 'Ius postliminii', jako podstawa uznania ciagtości I i II oraz II i III Rzeczypospolitej, Na szlakach Niepodlegtej. Polska myśl polityczna i prawna w latach 1918-1939, ed. M. Marszał, M. Sadowski, Wrocław 2009.

Symonides J., Terytorium państwowe w świetle zasady efektywności, Torun 1971.

Multan W., Symonides J., Powstanie Ludowej Republiki Bengalii - niektóre aspekty prawnomiędzynarodowe, "Sprawy Międzynarodowe"1972, no. 6.

Tyranowski J., Sukcesja rzq̨ów a identycznośćpaństwa (Zagadnienia teoretyczne), "Państwo i Prawo"1980, no. 4.

Antonowicz L., Powstanie i upadek państw, jako podmiotów prawa Międzynarodowego, “Sprawy Międzynarodowe”, 1968, no. 2.

Idem, Likwidacja kolonializmu ze stanowiska prawa miedzynarodowego, Warszawa 1964.

Dembiński L., Samostanowienie w prawie i praktyce ONZ, Warszawa 1969.

Herdegen M., Der Wegfall effektiver Staatsgewalt im Volkerrecht: "The Failed State", "Berichte der Deutschen Gesellschaft für Völkerrecht”, vol. 34, Heidelberg 1996.

Shaw M., International Law, Cambridge University Press, Cambridge 2003.

Kwiecień R., Status prawny i rola państw w spoteczności międzynarodowej a podmiotowe granice prawa międzynarodowego, Państwo i terytorium w prawie międzynarodowym, eds. J. Menkes, E. Cała-Wacinkiewicz, Warszaw 2015.

Kaur S., Self-Determination in International Law, "Indian Journal of International Law" 1970, vol. 10 .

Emerson R., Self-Determination, "American Journal of International Law”1971, vol. 65. Hubert S., Odbudowa państwa polskiego, jako problemat prawa narodów, Lwów 1934.

United Nations Legislative Series. Materials on Succession of States, New York 1967.

Grant T., The Recognition of States: Law and Practice in Debate and Evolution, Greenwood Publishing Group, Westport 1999. 
Hali W. E., A Treatise on International Law, Oxford 1909.

Góralczyk W., Prawo międzynarodowe publiczne w zarysie, Warszawa 1977.

Lenin W. I., O prawie narodów do samostanowienia, Dzieta wybrane, Warszawa 1949, t. 1. Czapliński W., Samostanowienie-secesja-uznanie (uwagi na tle inkorporacja Krymu do Federacji Rosyjskiej, Państwo i teryritorium w prawie międzynarodowym, eds. J. Menkes, E. Cała-Wacinkiewicz, Warszawa 2015.

Yearbook of the International Law Commission, 1975/II.

\section{SUMMARY}

\section{The Issues of Secession in the Process of the Rise and Fall of States in the Light of International Law}

The aims of this contribution is to check the validity of the old theory, which goes back to Jellinek but is still dominant, which states that secession as well as the process of forming a new state, fall under the scope of a "simple fact" and thereby escape through definition to any law of way. According to this theory, secession is not a question of "Law" but a question of pure fact, failure or success: if a secessionist movement succeeds in establishing a new effectiveness, that is to say, puts in place the "Constituent elements" of a state, a new state is born. It is interesting to observe that with the phenomenon of the rise or the collapse of States, from the global perspective of international order and especially from the point of view of international law, the States concerned are, in practice, not simply left to their fate. On the contrary, the rise or the collapse of a State anywhere in the world is seen as a matter of concern for the international community, since the international system as a whole is felt to be affected. In such cases, international reactions have not been manifested primarily through the States as such, either individually or together. Basically, these reactions had to cope with the dilemma of choosing between two fundamental principles of legitimacy in international law: on the one hand, the sovereignty and equality of States and, on the other, the right of peoples to self-determination.

Keywords: public international law, soft law, binding, international, legal standards, actors, cooperation

Boubacar Sidi Diallo, Adam Mickiewicz University Poznań, Faculty of Law and Administration, Al. Niepodległości 53, 61-714 Poznań, e-mail: diallo@amu.edu.pl. 
